\title{
A Risky Mode Of Foreign Market Entry: International Portfolio Investments
}

Ulku Yuksel, University of Sydney, Australia

Asli Yuksel-Mermod, Marmara University, Turkey

\begin{abstract}
There are various forms of entrance into foreign markets, varying in magnitude and direction of risks which may endanger either the investor or the host country. Some of the foreign market entry modes involve just financial investments with almost no risks, such as international portfolio investments, whilst others require an additional commitment from the investor's part. This twofold investment style; that is, money only versus money plus varied amounts of dedication, makes up the magnitude of the risk involved. While the former (money on shares only) may be considered unconventional, the latter (i.e., money plus commitment) entails traditional modes of foreign market entry. This study examines international portfolio investments, also called hot money, as a viable and unconventional foreign market entry alternative, triggered by the forces of globalization. Accordingly, the authors' point of view indicates a departure from conventional foreign market entry mode literature and draws on the resource based view (RBV) and eclectic theory of internationalization.
\end{abstract}

Keywords: Foreign market entry mode, International portfolio investment, Internationalization theories, Resource based view (RBV), Eclectic theory of internationalization, and International marketing

\section{INTRODUCTION}

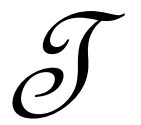

his study examines international portfolio investments as a viable foreign market entry alternative, triggered by the forces of globalization. Accordingly, the authors' point of view indicates a departure from conventional foreign market entry mode literature and draws on the resource based view (RBV) and eclectic theory of internationalization.

This study is organized as following: First, the authors explain the different traditional modes of foreign market entry, especially the foreign direct investments in detail, in the international marketing literature. Then, they bring in the unconventional mode of foreign market entry; that is, the international portfolio investments, into their arguments. Next, they discuss theories of foreign market entry modes; namely, internalization theory, eclectic theory and resources-based view of internalization. Then they explain how they incorporate international portfolio investments into foreign market entry modes by drawing on the eclectic theory and resources-based view of internalization. Finally, in the discussion and conclusion section, they explain the contribution of their study to the field of international marketing literature, both from scholarly and practical (managerial and governmental) perspectives, as well as detail areas for further research.

\section{TRADITIONAL MODES OF FOREIGN MARKET ENTRY}

There are various forms of entrance into foreign markets, varying in magnitude and direction of risks, either for the investor or for the host country. Some involve just financial investments with almost no risks, such as international portfolio investments, whilst others require an additional commitment from the investor's part. This two-fold investment style; that is, money only versus money plus varied amounts of dedication, makes up the magnitude of the risk involved. The latter (i.e., money plus commitment) entails traditional modes of foreign market entry. With reference to an increasing level of risks (although the order may be arguable); that is, up through a ladder from the less risky to the most risky from the investor's point of view, these traditional foreign market entry 
modes include:

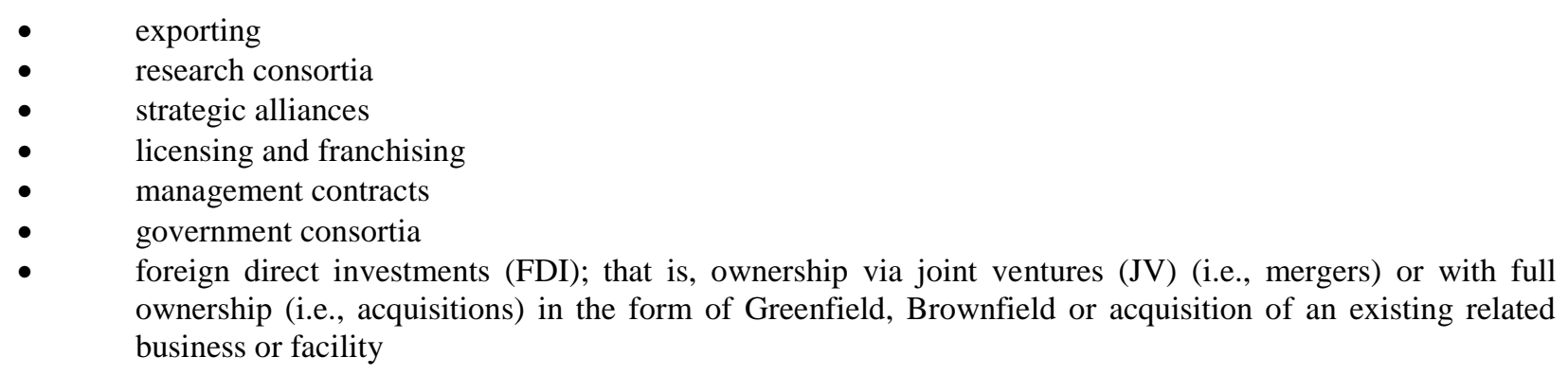
ownership (i.e., acquisitions) in the form of Greenfield, Brownfield or acquisition of an existing related business or facility

\section{Foreign Direct Investments (FDI)}

FDI, regardless of some or full ownership (merger or acquisition) of the entity, may take the form of mergers or acquisitions, as well as Greenfield projects and Brownfield projects.

\section{Greenfield Projects}

The basic differences of entering into a foreign market through a Greenfield, Brownfield or acquisition strategy is that in the Greenfield, the foreign investor invests in a land or project in a foreign country where no previous facilities exist. The investor builds new operational facilities from the ground up. The name suggests the idea of constructing a brand new facility literally on a "green" field, such as farmland. Hence, the investor has to do everything from a clean scratch on a clean land. Developing countries frequently provide these investors with taxbreaks, subsidies, free land and other types of incentives to set up green field investments because Greenfield projects create jobs, technology, and know-how, and they support the country's human capital.

\section{Brownfield Projects}

The Brownfield relates to a previously developed area or project, such as the location of a gas station, a parking site, or demolished construction or building. Generally, Brownfields involve some sort of a "dirty" business purpose, meaning dirty with its connection to pollution. The name suggests the idea of constructing a brand new and different facility, literally on a "brown and dirty" field. Examples include a steel mill or oil refinery, which is cleaned up and employed for a less polluting purpose, such as commercial office space or a residential area.

Both Greenfields and Brownfields may be in the form of full ownership or some ownership; that is, a partnership, such as a joint venture. Accordingly, they may involve mergers (partnerships with other businesses $(\mathrm{JV})$.

\section{Mergers and Acquisition (M\&A)}

The major justification for a merger and/or acquisition activity is improved financial performance which may be explained via the following motives:

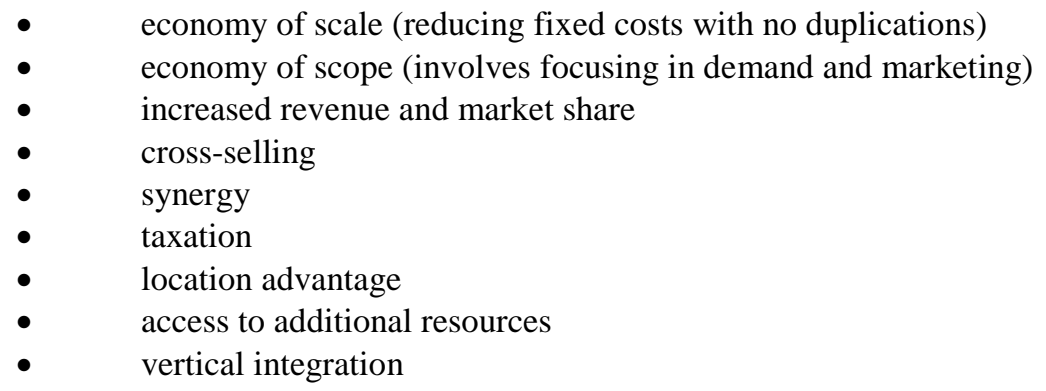




\section{Mergers}

Mergers are the combination of two or more businesses and entities into one through a purchase acquisition or a pooling of interests; for example, Citigroup. Citigroup Inc. (branded Citi) is a major financial services firm. As one of the world's largest mergers in history, it is the combination of the giant Citicorp and financial conglomerate, Travelers Group. When it comes to mergers, some are so successful that we cannot recall when the companies were distinct, such as Disney with Pixar, or J.P. Morgan with Chase; but many mergers are a failure in which the newly formed firm goes bankrupt, executives are fired, and, in some cases, the merged companies break up in a sort of corporate divorce (Schonfeld 2009). Some well known successful mergers include Disney-Pixar, Sirious-XM radio merger, and Exxon-Mobil, and unsuccessful mergers contain Daimler Benz-Chrysler and Sears-Kmart (Schonfeld 2009).

\section{Sole Acquisition}

Acquisition relates to acquiring (i.e., purchasing) an existing project or firm in some way related to the investor's business. Acquisitions are also called a takeover or a buyout in which a firm buys another (target) firm in a positive or negative manner. Specifically, both the firms cooperate in negotiations with willingness and compliance or the takeover target firm is unwilling to be purchased or even has no prior knowledge of the intention or offer. Often, a larger firm buys a smaller one in an acquisition. The largest announced deal of 2009 was Oracle's $\$ 7.4$ billion purchase of Sun Microsystems, which is still awaiting regulatory approval. Hewlett-Packard picked up 3Com for \$2.7 billion (No. 9) and Intel bought Wind River for \$884 million (No. 16) (Schonfeld 2009).

\section{A Different Perspective}

There is another alternative to all of these previously noted traditional foreign market entry modes. Specifically, this study contemplates that international portfolio investments, also called hot money, become a viable market entry alternative due to the forces of globalization in a departure from conventional literature and application of the resource-based view (RBV) and eclectic theory of internationalization. When it comes to international portfolio investments, it is important to understand what the portfolio investments are. Accordingly, we discuss portfolio investments next.

\section{PORTFOLIO INVESTMENTS}

Portfolio investments involve the acquisition of portfolio capital and usually refer to transactions across national borders and/or across currencies. In other words, portfolio investment is the purchase of stocks and bonds internationally. Specifically, portfolio investments are passive assets in the form of securities, such as foreign stocks, bonds or further financial and monetary possessions. The investor of portfolios does not actively operate with, manage, or control the issuer of the securities. Usually, the investor keeps less than $10 \%$ of the total shares or, at any rate, less than what is necessary to retain the majority vote.

Portfolio investments include purchase of shares in a foreign company, purchase of bonds issued by a foreign government, or acquisition of assets in a foreign country. That is, portfolio investments are some form of passive financial valuables. Financial valuables include financial (or cash) instruments, such as: 1) Securities, a certificate representing the ownership of a transferable and negotiable monetary value. Securities take the form of debt securities (bonds, banknotes, debentures; i.e., loan agreements) or equity securities (common stocks and equity shares of stocks; i.e., partnerships in corporations and common stocks); 2) Deposits, which is the action of putting money into a bank account; 3) Derivatives, which are agreements in the form of forwards (including futures), options and swaps. A forward is a written agreement contract to buy or sell an asset at a particular date in the future. The value of a derivative originates from the underlying worth of an asset (e.g., credits, mortgage loans for real estate, bonds, commodities, stocks), a manifestation (e.g., interest rates, exchange rates, consumer prices index, stock market listings), or various circumstances, some of which may be environmental; 4) goods or fungible commodities (e.g., wheat, currency); 5) Collectibles (precious items for particular collectors; e.g., antiques); and (6) Investments in real estate; i.e., buying, holding, and selling real estate. 
Foreign investors consider several factors in establishing an international portfolio investment. These factors include: 1) tax rates on interest or dividends (clearly, investors favor countries with comparatively low tax rates), 2) interest rates (investors prefer countries with high interest rates), and finally 3) exchange rates (an anticipation of local currency to strengthen will tempt and appeal to foreign investors). Specifically, if foreign investors are expecting a stronger position for the local currency, they will be attracted to invest in international portfolios and consequently foreign money will flow to countries with relatively low tax rates on interests and dividends and enter countries with high interest rates.

This transaction process of international money transfer into a different country is considered as an international portfolio investment from the foreign investor's perspective whilst it is a flow of a bulk of cash deposit into the country where the money moves in. Hence, this cash flow seems very attractive and "hot" for the receiving country. The name hot money stems from this description and perception. Accordingly, one may assert that international portfolio investment; that is hot money, is another form of a foreign market entry mode from the investor's perspective.

Hot money, a phenomenon which occurs in global financial markets, epitomizes sudden enormous monetary capital-flows into developing countries through foreign investors who buy securities ${ }^{1}$ from emerging markets, as well as the sudden outflow of capital from these economies. With the advent of the globalization phenomenon, we frame hot money as a possible market entry mode for foreign firms (investors) entering emerging markets to receive short-term and less risky returns on investments in the form of financial resources, along with location advantages.

Large amounts of capital flow into emerging markets leads to a financial boom in host countries. On the other hand, weak macro economic fundamentals are one of the major reasons for capital out-flows from emerging markets in the form of hot money. Furthermore, a significant drawback of hot money occurs when foreign investors withdraw money promptly from emerging markets. The nature of the portfolio investments is that they are very yield sensitive, volatile, of shorter duration (Tarzi, 2000) and are easily exposed to some information frictions, expectations, and herd behaviour of the investors (Chari \& Kehoe, 2003) in comparison to other forms of capital flows. Standard debt default problems of the host government also enhance the sudden withdrawal of foreign capital which then leads the host country to a financial crisis. We argue that the whole concept of hot money (capital flows) may be integrated with the theories of market entry and market entry modes.

In the case of hot money, international macro marketing involves country risk assessments (see Tarzi, 1997) and country marketing for international financial institutions from the host country's perspective. We argue, however, that not only will the macro marketing school of thought be allied to the fields of global finance, but marketing on the firm level in the home (and also host) countries will be affected by this practice of hot money. As such, this article tries to make an early and exploratory attempt to understand the phenomenon under the umbrella of marketing school of thought. To this end, this article applies the resource-based view (RBV) and several key tenets of the eclectic theory of internationalization to propose a broad framework to link hot money to the theories of market entry from the foreign investors' perspective. Essentially, we wonder whether this phenomenon of hot money is an alternative to the decisions of FDI or other forms of market entry (Goldstein \& Razin, 2003). The importance of this article, from the international marketing theory perspective, is that it attempts to add new insight to the market entry mode literature by linking two business and management disciplines; namely, marketing and finance. Additionally, managerial implications include providing international marketing managers an alternative perspective to their entry mode decision-making.

The forthcoming part of this article is structured as follows: First, we explain the hot money phenomenon and other forms of capital flows from international investors into emerging markets. Second, we discuss various entry modes and their underlying theories in the international marketing literature. Third, the eclectic and RBV theories of internationalization are applied to argue that hot money is a possible market entry mode for the foreign investors. We end the article with a series of research questions.

\footnotetext{
${ }^{1}$ Security is a piece of paper that proves ownership of stocks, bonds and other investments. Securitization refers to the replacement of nonmarketable loans and/or cash flows provided by financial intermediaries with negotiable securities issued in the public capital markets.
} 


\section{International Portfolio Investments, Hot Money}

Shifting huge amounts of money in and out developing countries promptly by letting international (home country) investors purchase shares, that is, securities in the forms of stocks and bonds, in financial markets of the host countries (emerging markets) is the core process, called hot money or hedge funds. From a developed country's macro economic perspective (such as the case with the USA and Japan) money going out from the home country quickly has its drawbacks in terms of deteriorating dynamics of financial markets and economy of the home country (developed country). On the other hand, on the firm level, this allows the international firm to obtain quick return on investment.

One of the reasons of capital flows from the home market (developed economy) to the emerging economy is associated with "declining long-term interest rates in the home countries which makes the fund managers decide on seeking higher-yielding emerging market financial assets" (Tarzi, 2000, 30).

From a macro economic perspective, large amounts of capital flow into emerging markets causes financial booms in the host countries, resulting in welfare since they enable households to achieve higher levels of consumption (Tarzi, 2000), and afford firms in developing countries the means to exploit promising investment opportunities (Bernanke, 2005) which makes them move into new financial resources through sold shares. However, potentially undesirable effects of hot money in the form of capital inflows for the host country may also be inflationary pressures caused by rapid monetary expansion, and the appreciation (increase in the value) of the exchange rates (Tarzi, 2000) in the host country. Nevertheless, the sudden out-flow of gigantic capital from the financial markets of the emerging markets causes financial crisis in the host (developing) countries (Chari \& Kehoe, 2003; Martin, Farrell \& Lund, 2000; Tarzi, 2000) resulting in severe negative impacts on macroeconomic stability and growth (Tarzi, 2000).

International capital flows in the form of hot money or hedge funds represent foreign portfolio equity ${ }^{2}$ investments which are investments in international financial markets that involve ownership of shares or units, through purchase of stock or mutual fund shares. That is, foreign investors and other global financial market participants purchase securities that are documents that prove ownership of stocks, bonds and other investments in the equity markets of foreign countries (Tarzi, 2000). These portfolio equity capital inflows to emerging markets signify hot money. Other forms of international capital flows are commercial bank lending, official government or international organization flows, such as IMF and World Bank, and FDI (Tarzi, 2000).

Financial booms and crises in developing countries are closely associated with such capital flows which are streaming in and out of emerging economies in the form of hot money caused by foreign investors buying equities in host countries financial markets (Chari \& Kehoe, 2003). However, there are also other reasons of the booms and crises apart from hot money triggered by funds, such as bank lendings; specifically, short term loans between banks without any long-term project financing (Baily, Farrel, \& Lund, 2000).

Financial crises caused by hot money have two main features. First, when the host country demonstrates weak macroeconomic fundamentals (see also Tarzi, 2001), then foreign investors tend to withdraw money from those emerging markets suddenly which results in a crisis arousal (Kaminski, 1999). Second, herd behaviour of foreign investors which is not always related to the host country's weak macroeconomic fundamentals (Chari \& Kehoe, 2003) instigates crisis. Macro economic fundamentals are important in causing crises in emerging economies. When fundamentals are strong in an economy then the capital in-flow is more likely to occur, and when fundamentals are weak the capital outflow is eminent (Kaminski, 1999). Weak fundamentals may produce some kind of anxiety, "jitters" among the investors, and such "movements are triggered by local and neighbor-country news, with news about agreements with international organizations and credit rating agencies having the most weight. However, some of those large changes cannot be explained by any apparent substantial news, but seem to be driven by herd instincts of the markets itself. The evidence suggests that investors over-react to bad news," (Kaminski, 1999). This explains the roles of informational frictions in international financial markets, and standard dept default problems in emerging markets in generating herdlike capital flows resembling hot money (Chari \& Kehoe, 2003).

\footnotetext{
${ }^{2}$ Equities are investments that involve ownership of shares or units, through purchase of stock or mutual fund shares.
} 


\section{Herd Behaviour}

Herd behaviour is "a sequential decision model in which each decisionmaker (foreign investors) looks at the decisions made," (Banerjee, 1992) by previous decisionmakers (foreign investors) in making their personal particular choice. This is rational for the followers who are showing herd behaviour by pursuing what the others have done because these other decisionmakers (the preceding foreign investors) "may have some information that is important," (Banerjee, 1992) for the subsequent investors. "The decision rules that are chosen by optimizing individual foreign firms will be characterized by herd behaviour; i.e., firms will be doing what others are doing rather than using their own information, yet, the resulting equilibrium is mostly inefficient," (Banerjee, 1992). The herd behaviour phenomenon explains the sudden capital withdrawal with no consideration of the weak fundamentals of the host country; they just follow what the others do according to the information of others behaviours rather than market conditions. Hence, capital flows depend on the specific pattern of the realization of signals across investors (Chari \& Kehoe, 2003).

This phenomenon of herd behaviour of foreign investors may be linked to the expectancy theory (see Vroom, 1964) which argues that as investors constantly are predicting likely futures, they create expectations about future events (Vroom, 1964) by looking at what the other foreign investors are doing. Expectancy theory has some underlying assumptions: first, things should seem reasonably likely (by observing behaviours of the foreign investors), second conditions should seem attractive (with their assumptions of that the preceding investors know better, hence, following their behaviour would results in less risks and more profits), third, the followers should know how to get there (by just doing the same as the previous group did), and fourth followers should be able to act as the others do. The presence of these assumptions will motivate the followers to act to make this future come true by following the leading groups' behaviour. Furthermore, the expectancy theory expounds that the following groups assume that others (the leading investors) may have some information that is important.

The emphasis in international marketing has been on traditional market entry strategies, such as joint ventures and exporting. However, as a corollary of globalization, new forms of market entry modes provide new, adventurous and exciting opportunities; one such opportunity is that of hot money. Some of the aspects of globalization may be summarized as the free flow of capital globally, the concentration of hundreds of billions of dollars in the hands of very few large funds whose aim is maximum short term return, the lack of liquidity of the markets that attract hot money, the herd mentality of the investors, and a need to increase the volume of speculative investments as opportunities for easy profits decrease (Jacksson, 2005).

In fact, free global capital flow is a recent phenomenon which enhances the forces promoting globalization. This concept attracts primarily the transnationals since it is less risky and demands no commitment which is a core concept for an FDI. These investors of hedge funds invest in moving funds, namely, a number of massive equity funds and pension funds, looking for the maximum short term return on their funds. Money is invested in most attractive equity markets and the money is withdrawn, when a better opportunity arises. They have no loyalty to country, employees, local communities, and no regard for the cultural traditional of their host countries. The only thing of importance is money. Furthermore, the investors invest slowly and exit en mass, akin to herd behaviour (Jacksson, 2005). Clearly, advanced information technologies, and easy and quick flow of information has reinforced globalization of international capital markets. And this globalization of financial markets with the support of endorsed greater diversification enables portfolio investors to invest in many different emerging economies.

Next, we explain market entry and theories of entry modes together with the link to the phenomenon of hot money.

\section{THEORIES OF ENTRY MODES}

The identification and implementation of an appropriate entry strategy has critical implications for a firm's competitive performance and survival (Terpstra \& Sarathy, 1994). Furthermore, as the entry modes are related to control, commitment of resources and risks in investment (Calvet, 1984) it has implications at both strategic and the tactical levels of a firm intending to enter new markets (Ekeledo \& Sivakumar, 2004). There are several different entry modes currently available for firms. They include exporting (which is the most common entry mode and 
involves the least financial risk), licensing (which involves allowing a local firm to use the foreign company's know-how for a fee), joint venture (where two companies form a new firm, and which is a low risk entry strategy), and partially owned and wholly owned subsidiaries (FDI), this encompassing the highest risk as well as potentially providing the highest returns (Sharma, 2000). In explaining these different market entry modes, several theoretical frameworks have been developed. These theoretical frameworks are important as they aid in adopting the appropriate entry strategy. Malhotra, Ulgado and Agarwal (2003) list several theories that they believe provide the theoretical foundation for most of the research in this area. These theories include; international product life cycle, market imperfection theory, strategic behaviour theory, resource advantage theory, transaction cost analysis theory, eclectic theory of international product, internationalization theory, and network theory.

Three theories are argued to be most widely accepted as they have body of empirical evidence (Ekeledo and Sivakumar, 2004). These theories include the internalization theory, eclectic theory and the resource-based theory of entry modes.

\section{Internalization Theory}

The first one, the internalization theory, highlights what motivates a firm in operating a facility in the foreign market instead of adopting less risky entry mode, such as licensing. This theory emphasises Transaction Cost Analysis; some researchers even argue that both these theories are in fact, one (Rugman, 1980). Transaction cost analysis has been a dominant paradigm explaining foreign entry modes. The choice of the entry mode essentially depends on the trade-off between control and the cost of commitments of resources. The transaction cost analysis theory is embedded in the institutional economics paradigm, where the governance structure of the firm is of importance (Malhotra et al. 2003). Essentially, internalization theory argues that lower level modes of entry (licensing and contracts) are the preferred entry modes, unless there is viable argument for other more risky entry modes. This theory suggests that costs of undertaking economic exchange may be more than the cost of organizing the exchange within the firm.

\section{Eclectic Theory}

The second, the eclectic theory, emerges from the limitations of the internalization theory and other theories. Basically, eclectic theory argues that other theories by themselves cannot explain the choice of FDI over other modes, such as exporting. Dunning (1988) suggests that eclectic theory foundations are based on three advantages; ownership, location, and internalization advantages. For FDI to be beneficial to a foreign firm, following three advantages must be present; first the firm must possess firm or product specific advantages through the possession of or access to income generating assets; second, location specific advantages, which allow the firm to earn more outside of the home country than in the local markets; and finally, market internalization which permits the firm to make the most of a foreign opportunity (Chandra, Styles, \& Wilkinson, 2005). The whole concept suggests that internationalisation decisions are rational resolutions since they consider cost of transaction (Whitelock, 2002).

More specifically, ownership advantage provides a foreign firm with competitive advantage and a full control, and facilitates the firm by counteracting the advantages that local firms have. Location advantages highlight the market potential and country risks which provide an opportunity for the firm to conduct business in a foreign market profitably. Internalization advantages suggest that FDI is more profitable than licensing to a local firm due to the risks in the contracts (Agarwal \& Ramswami, 1992). Eclectic paradigm includes a multi-theoretical approach that takes the RBV into consideration owing to its emphasis on ownership advantages, international trade theory on account of location advantage, and finally transaction cost analysis theory for its claim on internalization advantage. The eclectic theory is important in explaining hedge fund investments since the investors behaviours borrow from the location advantage of the eclectic paradigm due to its link with international trade theory.

\section{Resource-based View}

Third, RBV argues that in order to understand the dynamism of an organisation's competitive actions, understanding the growth of the firm in terms of its resource and capabilities, and the way they use the resources are 
important (Coates \& McDermott, 2002). The RBV has come about due to the limitations of the industrial organisation perspective as some researches have criticised the industrial organisation perspective for its inability to rigorously explain the intra-industry heterogeneity in performance (Hawawini, Subramanian, \& Verdin 2003). For example, given that in an industry with identical conditions of supply and demand that operated under the same market structure, why do some firms within the same industry perform better than others? Nelson (1991) argues that the focus of the industrial organisation perspective on industry factors effectively ignores the discretionary choices that organisations make, and that these choices are not identical across all firms within an industry. RBV has its origins in evolutionary economics and in particular the economist, Penrose (1959) who argues that "services yielded by resources are a function of the way in which they are used - exactly the same resource when used for different purposes or in different ways and in combination with different types or amounts of other resources provides a different service or set of services" (p. 25). This suggests that the uniqueness of the organisation is based on the way the organisation bundles resources.

In the context of entry modes, RBV, unlike other theories, not only explains both the differences in the choices of firm entry modes, but also elucidates why some companies adopt entry modes strategies that will not yield above normal returns. It builds on the theory of comparative advantage to argue that a firm will enter international markets by exploiting its capabilities, and the entry mode depends on the resource type. Essentially RBV argues that by exploiting resource embedded through internalization, firms choose their market entry modes. However, a limitation of RBV is that it does not fully explain certain types of cooperative entry modes, such as joint ventures (Malhotra et al. 2003).

Next, we discuss and try to illuminate the significance of the concept of hot money as a theoretical framework for the international marketing literature.

\section{INTEGRATING INTERNATIONAL PORTFOLIO INVESTMENTS AND MARKET ENTRY THEORIES}

Having reviewed the key theories of entry modes, the article adopts key tenets of the RBV and the eclectic theory and suggests that apart from the traditional methods of entry modes, a viable option is that of hot money, through the capital markets. Firstly from the RBV perspective, there are several classifications of resources; 1) resources can be broadly categorised as financial, physical, human, commercial and technological assets used by firms to develop, manufacture, or deliver products and services to its customers (Barney, 1991); 2) as tangible (physical or financial) or intangible (employees' knowledge, experiences and skills, brand name, organisational procedures) (Grant, 1991), and; 3) as operand resources and operant resources. Operand resources are those resources "on which an operation or act is performed to produce an effect" and operant resources "are resources that produce effects" (Vargo \& Lusch, 2004, p. 2). As firms choose their market entry modes by exploiting resources embedded through internalization from a RBV perspective, hot money can be conceptualised as a financial and an operant resource. Secondly, from the eclectic perspective, hot money can be viewed as occurring due to location advantages. For example, location advantages highlight the market potential and country risks which provide an opportunity for a firm to conduct business in a foreign market profitably. Foreign firms investing in a particular country, via hot money, primarily enter emerging countries due to their economic environments. Therefore, when fundamentals are strong in an economy then the capital in-flow is more likely to occur (location advantage of the country), and when fundamentals are weak, capital outflow is eminent (location disadvantage of the country) (Kaminski, 1999). Furthermore, eclectic theory suggests that internationalisation decisions are rational resolutions since they consider costs of transactions. Likewise the rationale behind inflows of hot money is a rational decision (moving into a country to take advantage of economic conditions), as is the case with the withdrawal of hot money. More specifically, exiting a country due to the sudden changes in the economic environment is a rational decision from the foreign investor's perspective.

Next, we conclude and point out the managerial implications and highlight some future research questions.

\section{DISCUSSION AND CONCLUSION}

From the international marketing theory perspective, this article adds new insight to the market entry mode literature by linking the fields of marketing and finance. Essentially, this article discusses whether the phenomenon 
of hot money is an alternative to the decisions of FDI or other forms of market entry applying the key tenets of the RBV and the eclectic theories. For example, it is argued that hot money is a financial and an operant resource for the investing firm and that the decision to invest in hot money is a rational decision based on location advantages from the foreign investor's perspective.

Managerial implications endow international marketing managers with an alternative perspective to their entry mode decision-making and let them review whether the whole concept could be a genuine choice over traditional market entry modes. Consideration of hot money as a market entry strategy allows international marketing managers an optional market entry strategy with increased flexibility, less commitment and risk, and an initial entry into a country. However, managers must be aware of the advantages and disadvantages of hot money, particularly from the negative economic and social effects that sudden withdrawal may have on the host country.

Due to the exploratory nature of this article, various research opportunities arise for researchers. For example, do capital flows in the form of hot money restrain capital flows in the form of FDI? Do capital flows in the form of hot money have a significant impact on the market entry strategies of foreign firms into emerging markets? Does the investment in hot money create a competitive advantage to firms in emerging markets as it increases their resource base, and facilitates in building financial network alliances? What are the other effects of capital flows in the form of hot money on firm capabilities in the host countries? Does the economic crisis caused by withdrawal of hot money affect local firm capabilities? Under which circumstances, to what extent, and how do the sudden withdrawals of capitals affect firm capabilities?

\section{AUTHOR INFORMATION}

Dr. Ulku Yuksel is an Assistant Professor in Marketing at the University of Sydney since 2004. Dr. Ulku Yuksel's research interests include cross-cultural marketing, international marketing and consumer behaviour. Specifically, culture, decision-making and consumption under risk, uncertainty, and stress, as well as anti-consumption and political marketing (e.g., boycott behaviour) are the sub-areas she is interested in within this broad concept. Her recent researches explore people's (i.e., consumers or entrepreneurs) evaluations and decisions as consumers involved in various levels and types of risks.

Dr. Asli Yuksel Mermod is an Associate Professor of Finance in the Department of English Business Administration at Marmara University. She works as visiting finance professor at Weber University in GenevaSwitzerland and at Bahcesehir University-Istanbul. She has her MBA and Ph.D. in Finance from Marmara University Banking and Insurance Institute. Her research areas cover Bank Management, Bank Marketing, Socially Responsible and Ethical Investing, Energy Finance, Brand Equity, Financial Services Marketing, Tourism Investments, and Corporate Finance.

\section{REFERENCES}

1. Agrawal, S. \& Ramaswami, S.N. (1992). Choice of foreign market entry mode; impact of ownership, location and internalization factors. Journal of International Business Studies. 23, 1-27.

2. Banerjee, A. V. (1992). A simple model of herd behaviour. The Quarterly Journal of Economics, MIT Press, 107 (3), 797-817.

3. Barney, J. (1991). Firm resources and sustained competitive advantage. Journal of Management, 17, 99120.

4. Bernanke, B. S. (2005). Monetary policy in a world of mobile capital. Cato Journal, 25 (1), 1-12.

5. Calvet, L. (1984). A synthesis of foreign direct investment theories and theories of the multinational enterprise, Journal of international Business Studies, 12, 43-59.

6. Chandra, Y. \& Styles, C., Wilkinson, I. (2005). The discovery of international entrepreneurial opportunities: Insights from knowledge-based industries. AGSE Regional Entrepreneurship \& Innovation Research Exchange 2005, Swinburne University of Technology, Melbourne, 10-11 February.

7. $\quad$ Chari, V.V., \& Kehoe, P. J. (2003). Hot money. The Journal of Political Economy, Dec, 111 (6), 12621292. 
8. Coates, T.T. \& McDermott, C.M. (2002). An exploratory analysis of new competencies: a resource based view perspective. Journal of Operations Management. 20, 435-450.

9. Dunning, J.H. (1988). Towards an eclectic theory of international production; some empirical tests. Journal of International Business Studies, 19, 1-31.

10. Ekeledo, I. \& Sivakumar, K. (2004). International market entry mode strategies of manufacturing firms and service firms: a resource based perspective. International Marketing Review. 21, 68-101.

11. Goldstein, I. \& Razin, A. (2003). An Information-Based Trade-off Between Foreign Direct Investment and Foreign Portfolio Investment: Volatility, Transparency and Welfare," CEPR Discussion Papers 3747, C.E.P.R. Discussion Papers.

12. Grant, R.M. (1991). The resource based theory of competitive advantage: implications for strategy formulation. California Management Review, 33, 114-135.

13. Hawawini, G., Subramanian, V. \& Verdin, P. (2003). Is performance driven by industry or firm-specific factors? A new look at the evidence. Strategic Management Journal. 24, 1-16.

14. Jackson, R. (2005), Hot money. Retrieved November 01, 2005, from http://www.rossjackson.com/copy of books/hotmoney.htm

15. Kaminsky, G. L. (1999). Currency and banking crises : The early warnings of distress. Working Paper. 99 (178), Washington: Internat. Monetary Fund, December.

16. Malhotra, N, K., Ulgado, F.M. \& Agarwak, J. (2003). Internationalization and entry modes: a multitheoretical framework and research propositions. Journal of International Marketing. 11, 1-31.

17. Martin, N. B., Farrell D., \& Lund S. (2000). The color of hot money. Foreign Affairs, Mar/Apr 79 (2), 99109.

18. Nelson, R.R. (1991) Why do firms differ, and how does it matter? Strategic Management Journal, 12, 6174.

19. Penrose, E. (1959), The Theory of Growth of the Firm, Oxford, Blackwell.

20. Rugman, A.M. (1980). Internalization as a general theory of foreign direct investment; a reappraisal of literature. Welwirtschafliches Archiv, 116, 365-379.

21. Sharma, A. (2000). Determinants of entry strategies of U.S. companies into Russia, the Czech Republic, Hungary, Poland and Romania. Thunderbird International Business Review, 42, 651-676.

22. Schonfeld, E. (2009), Top Tech Acquisitions of 2009 at http://www.techcrunch.com/2009/12/18/top-techacquisitions-2009/ retrieved $20^{\text {th }}$ Jan, 2010.

23. Tarzi, S. M. (2001). Attracting portfolio capital inflows: National political and economic attributes of emerging markets. The Journal of Social, Political, and Economic Studies. Summer 26 (2), 461-485.

24. Tarzi, S. M. (2000). Hot money and the emerging markets: Global political and economic determinants of portfolio capital flows. The Journal of Social, Political, and Economic Studies, Spring 25 (1), 27-49.

25. Tarzi, S. M. (1997). Country risk analysis, international banking and developing countries. The Journal of Social, Political, and Economic Studies, Winter 22 (4), 481-495.

26. Terpstra, V. \& Sarathy, R. (1994). International Marketing, $6^{\text {th }}$ ed. Dryden Press, Fort Worth, TX.

27. Vargo, S.L \&Lusch, R.F. (2004). Evolving to a new dominant logic for marketing. Journal of Marketing, $68,1-17$.

28. Vroom, V. H. (1964). Work and motivation. New York: Wiley

29. Whitelock, J. (2002). Editorial. International Marketing Review, 19 (4), 342.

30. Williams, B. (1997). Positive theories of multinational banking: eclectic versus internationalisation theory. Journal of Economic Surveys, Blackwell Publishing, 11 (1), 71-100. 